\title{
EVALUASI KELAYAKAN BISNIS PADA RUMAH PEMONDOKAN (KOST) MAHASISWA DI SEKITAR UNIVERSITAS MUHAMMADIYAH MALANG
}

\author{
Hellen Mayora Violetha \\ Department of Management FEB UMM \\ E-mail: faceless_void21@yahoo.com
}

\begin{abstract}
The purpose of the study is to evaluate the feasibility of students boarding house around University of Muhammadiyah Malang. The analytical tool are Net Present Value, Payback Period, Average Rate of Return, Internal Rate of Return, Profitability Index.The results of the analysis of boarding house owned by Mr. Rofiq show that the Net Present Value is 226.968.193,1 rupiahwhich is more than null (eligible). Value Payback Period is six years one month and seven days which is less than 20 years (feasible). Internal Rate of Return is 17,2063\% which is higher than COC, it is declared eligible.The value of Average Rate of Return is 43 $\%$ which is more than $15 \%$ (feasible). The value of Profitability Index is 1,44 which is more than one (feasible).The results of the analysis of boarding house owned by Mrs. Atnah show that Net Present Value is 22.370.869,3 rupiah which is more than null, it is declared eligible. Value Payback Period is twelve years two months and twentythree days is less than 20 years (feasible). Internal Rate of Return is 17,8111\% which is higher than COC, it is declared eligible. The value of Average Rate of Return is $38 \%$ which is more than $17 \%$ (feasible). The value of Profitability Index is 1.058 which is more than one (feasible). In other words, the investments wasconducted by both the owner of boarding house was proceed.The results of the analysis of boarding house owned by Mr. Sofi show that Net Present Value is minus 170.035.625,2 rupiah which is not more than null (unfit). Value Payback Period is 32 years 2 months 12 days is more than 20 years (not feasible). The results of the value of the Internal Rate of Return is 3,7435\% is less than COC which is declared unfit. The value of Average Rate of Return is $2 \%$ which is not expected (less than 15\%) declared unfit. The value Profitability Index is 0.32 which is less than one, it is declared unfit.
\end{abstract}

Keywords:Net Present Value, Internal Rate of Return, Payback Period, Average Rate of Return, Profitability Index.

\section{PENDAHULUAN}

Kota Malang telah dikenal sebagai Kota Pendidikan, maka dari itu perkembangan pendidikan di Kota tersebut sangat pesat. Hal ini terlihat dari banyaknya jumlah universitas baik negeri maupun swasta, selain ituKota Malang dipenuhi berbagai sekolah, lembaga pendidikan nonformal atautempat-tempat kursus, serta sejumlah pondok 
pesantren.Pendidikandi Kota Malang memiliki

fasilitas penunjang yang cukup memadai seperti tempat pemondokan, toko buku, super market, plaza, pusat pelayananan kesehatan masyarakat serta fasilitas penunjang lainnya yang tak kalah penting adalah adanya angkutan umum (transpotasi) yang tersedia ke penjuru kota (memiliki 25 jalur), yang menghubungkan 3 (tiga) terminal yang ada di Kota Malang, yaitu terminal Arjosari (arah Surabaya), terminal Gadang (arah Blitar), terminal Landungsari (arah Jombang/Kediri).

(www.malangkota.go.id)

Dewasa ini menyebabkan munculnya sebuah peluang usaha rumah pemondokan. Kota Malang merupakan potensi daerah yang memiliki nilai jual dan daya saing baik di tingkat regional maupun nasional. Dalam era globalisasi dunia pendidikan menghadapi berbagai tantangan dalam menghadapi perubahan yaitu dengan adanya tuntutan masyarakat memperoleh fasilitas pendidikan yang baik dan berkualitas.

Persaingan dunia usaha di era globalisasi ini telah mengalami kemajuan yang sangat pesat. Hal ini ditandai dengan berdirinya usahausaha baru mulai dari usaha makanan, pakaian, percetakan, kostkostan, dan sebagainya. Banyaknya peluang usaha dan keinginan manusia untuk mandiri dalam mendapatkan penghasilan dan didukung dengan banyaknya jumlah penduduk menyebabkan banyak orang mendirikan sebuah unit usaha baru, baik itu perusahaan dalam skala besar maupun perusahaan dalam skala kecil.

Hal ini dapat memberi pengaruh positif dari sisi pertumbuhan ekonomi. Namun ketatnya persaingan ekonomi membuat pengusaha harus mengetahui bagaimana caranya membuat sebuah usaha agar dapat bertahan dan berkembang di era globalisasi ini. Pengusaha perlu mengupayakan peningkatan efisiensi dan efektivitas pengelolaan usaha agar mampu mencapai hasil yang optimal dari sumber daya yang tersedia. Hal ini berkaitan dengan keputusan investasi yang tepat guna, karena keputusan investasi yang tepat akan memberi keuntungan finansial bagi pemilik, dan keuntungan bagi ekonomi makro. Sebaliknya jika keputusan investasi salah akan berdampak macetnya sebuah usaha.

Mendirikan suatu usaha diperlukan strategi yang tepat agar usaha dapat terus bertahan dan berkembang. Dalam mempertahankan sebuah usaha, pemilik perlu membuat perencanaan dan membuat keputusan investasi yang tepat. Banyak kendala yang dihadapi oleh pengusaha kecil dan menegah dalam menjalankan dan mempertahankan usahanya. Maka dari itu diperlukan analisis studi kelayakan bisnis yang dapat memudahkan pemilik dalam membuat perencanaan dan membuat keputusan investasi, selain itu dapat menilai sebuah usaha apakah usaha tersebut layak atau tidak.

Studi kelayakan bisnis merupakan penelitian terhadap rencana bisnis yang tidak hanya menganalisis layak atau tidaknya bisnis di bangun, tetapi juga saat 
dioperasikan secara rutin dalam rangka pencapaian keuntungan yang maksimal untuk waktu yang tidak ditentukan. Manfaat dari studi kelayakan bisnis adalah pemilik usaha dapat mengetahui sumber informasi yang berkaitan dengan usahanya dari berbagai aspek yang dapat dijadikan sebuah keputusan investasi.

Malang merupakan salah satu kota yang menjadi tujuan perantauan oleh orang-orang dari luar kota maupun luar pulau. Salah satu alasannya adalah karena banyaknya sarana pendidikan tersedia. Hal itu menyebabkan banyaknya pendatang di Malang baik untuk menempuh pendidikan di perguruan tinggi, maupun untuk bekerja. Maka dari itu, banyak orang memanfaatkan peluang tersebut dengan mendirikan usaha rumah pemondokan (kost) mahasiswa. Usaha semacam ini sangat berpotensi karena minat konsumen yang terus-menerus mencari dan membutuhkan rumah pemondokan (kost).

Rumah pemondokan merupakan jasa penginapan bagi sebagian orang yang membutuhkan lokasi tempat tinggal sementara agar mudah menjangkau lokasi yang dijadikan tempat menempuh pendidikan ataupun tempat bekerja. Rumah pemondokan terbagi menjadi beberapa macam, yaitu rumah pemondokan yang murni tanpa ada pemiliknya yang tinggal bersama, rumah pemondokan yang tinggal bersama dengan pemilik rumah, karena ada rumah tangga yang memiliki kelebihan ruang dan memiliki potensi untuk dibuat usaha kost, dan berikutnya ada seorang dengan sengaja membeli rumah kemudian dijadikan sebuah tempat kost.

Beberapa usaha yang menyediakan jasa kost seperti kategori kost yang telah dijelaskan sebelumnya berada di kawasan Universitas Muhammadiyah Malang. Rumah pemondokan murni tanpa ada pemiliknya yang tinggal bersama adalah milik Bapak Rofiq dengan fasilitas 22 kamar, kemudian rumah pemondokan yang tinggal bersama dengan pemilik adalah kost milik Ibu Atnah dengan fasilitas 15 kamar, dan yang terakhir ada seorang dengan sengaja membeli rumah kemudian dijadikan sebuah tempat kost adalah milik Bapak sofi.

Rumah pemondokan (kost) mahasiswa di sekitar Universitas Muhammadiyah malang ini memiliki kelebihan dan kekurangan masingmasing. Dari ketiga usaha tersebut, bila ditinjau dari sisi pendapatan ratarata mengalami peningkatan setiap tahunnya dan setiap rumah pemondokan (kost) tarifnya berbedabeda disesuaikan dengan fasilitas yang disediakan. Adapun data mengenai pendapatan usaha rumah pemondokan (kost) di sekitar Universitas Muhammadiyah Malang (UMM) dapat disajikan pada Tabel 1.

Tabel 1 menunjukkan data pendapatan usaha rumah pemondokan (kost) mahasiswa di sekitar Universitas Muhammadiyah Malang menggunakan data 3 tahun terakhir. Untuk kriteria murni kost, pendapatan setiap tahun dari tahun 2011 sampai 2013 mengalami kenaikan, untuk kriteria rumah tangga yang memanfaatkan kelebihan ruangnya untuk kost pendapatan selalu naik dari tahun 2011 sampai 2013 dan yang terakhir seorang yang 
membeli rumah untuk dijadikan kost/kontrakan, pendapatannya tetap di tahun 2011 sampai 2012 namun naik pada 2013, hal inirelative kecil dibandingan

dengan rumah pemondokan lainnyayang sama dengan kriteria rumah pemondokan milik Bapak Sofi.

Tabel 1. Pendapatan usaha rumah pemondokan tahun 2011-2013 (dalam Rupiah)

\begin{tabular}{|c|c|c|c|c|}
\hline Nama & 2011 & 2012 & 2013 & Keterangan \\
\hline $\begin{array}{c}\text { Kost } \\
\text { Bapak } \\
\text { Rofiq } \\
\text { (Murni } \\
\text { Kost) }\end{array}$ & 117.960 .000 & 128.520 .000 & 139.080 .000 & $\begin{array}{c}\text { Jumlah } \\
\text { kamar } \\
\text { sebanyak } 22\end{array}$ \\
\hline $\begin{array}{l}\text { Kost Bu } \\
\text { Atnah } \\
\text { ( Rumah } \\
\text { Tangga) }\end{array}$ & 65.700 .000 & 69.300 .000 & 72.000 .000 & $\begin{array}{c}\text { Jumlah } \\
\text { kamar } \\
\text { sebanyak } 15\end{array}$ \\
\hline $\begin{array}{c}\text { Rumah } \\
\text { Bapak } \\
\text { Sofi } \\
\text { yang di } \\
\text { beli } \\
\text { untuk } \\
\text { kost }\end{array}$ & 9.000 .000 & 9.000 .000 & 10.000 .000 & $\begin{array}{c}\text { Jumlah } \\
\text { kamar 2, } \\
\text { kamar } \\
\text { mandi, } \\
\text { dapur, luas } \\
\text { tanah } 136 \\
\text { m2, dan luas } \\
\text { bangunan } 54 \\
\text { m2 }\end{array}$ \\
\hline
\end{tabular}

Dari ketiga rumah pemondokan tersebut, pendapatan yang diperoleh dari kost milik Bapak Rofiq menunjukkan adanya peningkatan, dan pendapatan milik Ibu Atnah mengalami peningkatan namun kenaikannya tidak sebanyak kost Bapak Rofiq, dan rumah milik Bapak Sofi, harga yang ditawarkan terlalu kecil sehingga pendapatan yang diperoleh dari rumah tersebut sangat minim meskipun ada kenaikan.

Berdasarkan data yang diperoleh, menunjukkan usaha rumah pemondokan cenderung meningkat dan selalu diminati oleh pasar. Hal ini perlu ditindak lanjuti apakah ketiga usaha tersebut layak dilanjutkan atau tidak sehingga tujuan dari penelitian ini adalah untuk mengetahui dan mengevaluasi kelayakan usaha rumah pemondokan (kost) mahasiswa di sekitar Universitas Muhammadiyah Malang.

\section{TINJAUAN PUSTAKA}

Penelitian yang dilakukan oleh Wahyu Sutrisno yang diadakan pada tahun 2013 yaitu evaluasi kelayakan bisnis pada usaha jasa king laundry. Penelitian ini bertujuan untuk menganalis layak atau tidak layak usaha jasa King Laundry. Penelitian ini menggunakan metode penilaian investasi yaitu PP (Payback Period), NPV (Net Present Value), IRR (Internal Rate of Return), ARR (Average rate of return), dan PI (Profitability Indeks). Variabel yang digunakan dalam peneltian ini adalah aspek studi kelayakan bisnis yang terdiri dari aspek pasar dan pemasaran, aspek teknis dan teknologi, aspek manajemen dan organisasi, aspek ekonomi dan social, dan aspek keuangan.

Berdasarkan hasil analisis capital budgeting menunjukkan bahwa Nilai Payback Period (PP) < umur investasi 5 tahun yaitu sebesar 3 tahun 5 bulan 7 hari. Nilai $\mathrm{Net}$ Present Value (NPV) sebesar Rp1.194.615,53, nilai Internal Rate of Return (IRR) sebesar 18,678\% > COC, Nilai Average Rate of Return (ARR) sebesar 62,78\% > tingkat keuntungan yang diharapkan dan PI sebesar 1,03>1. Dari hasil penelitian yang dilakukan tersebut dapat disimpulkan bahwa usaha jasa King Laundry layak untuk dilanjutkan.

Investasi menurut Haming dan Basalamah (2003:3) secara umum diartikan sebagai keputusan 
mengeluarkan dana pada saat sekarang untuk membeli aktiva riil (tanah, rumah, mobil, dan sebagainya) atau aktiva keuangan (saham,obligasi, reksadana, wesel dan sebagainya) dengan tujuan untuk mendapatkan penghasilan yang lebih besar di masa yang akan datang.

Studi kelayakan bisnis dalam arti sempit adalah merupakan penelitian terhadap rencana bisnis yang tidak hanya menganalisis layak atau tidaknya suatu bisnis dibangun, tetapi juga pada saat bisnis tersebut beroperasi secara rutin dengan berhasil untuk memperoleh keuntungan yang maksimal secara ekonomis.

Studi kelayakan bisnis dalam arti luas adalah penelitian yang mendalam tentang dapat tidaknya atau layak tidaknya rencana bisnis dilakukan dengan berhasil dan menguntungkan (tidak hanya keuntungan ekonomis/finansial), akan tetapi cenderung melihat kemanfaatan yang lebih luas (makro) bagi daerah atau lokasi dimana bisnis tersebut dilaksanakan.

Kasmir dan Jakfar (2003) dalam bukunya studi kelayakan bisnis menyatakan studi kelayakan bisnis adalah suatu kegiatan yang mempelajari secara mendalam tentang suatu kegiatan atau usaha atau bisnis yang akan dijalankan, dalam rangka menentukan layak atau tidak usaha tersebut dijalankan.

Tujuan pentingnya melakukan studi kelayakan bisnis menurut Sucipto (2010:5): Menghindari risiko kerugian, memudahkan perencanaan, memudahkan pelaksanaan pekerjaan, memudahkan pengawasan, memudahkan pengendalian.Menurut
Sucipto(2010:4) dalam bukunya ruang lingkup studi kelayakan bisnis menyatakan terdapat tiga manfaat yang ditimbulkan dari adanya studi kelayakan bisnis, yaitu : 1) Manfaat financial,2)Manfaat ekonomi nasional, 3) Manfaat sosial

Aspek pasar dan pemasaran merupakan aspek yang harus diperhatikan dalam memulai sebuah usaha, karena sekecil apapun sebuah usaha harus memiliki pasar yang jelas dan memiliki strategi serta kebijaksanaan pengelolaan pemasaran yang tepat guna. Aspek pemasaran berisi rencana-rencana yang akan dilaksanakan dalam pemasaran produk, serta beberapa data yang mendukung rencana tersebut. Studi pasar akan memberikan gambaran mengenai intensitas persaingan, informasi tentang kebutuhan dan keinginan konsumen, pendapatan rata-rata calon konsumen, ketersediaan saluran distribusi, dan kondisi sarana angkutan.

Aspek Teknis dan Teknologi merupakan aspek yang berkaitan dengan kapasitas proyek, lokasi, tata letak alat produksi, bentuk bangunan (bertingkat atau tidak), kajian atas bahan dan sumbernya, desain produk, dan analisis biaya produksi.

Aspek manajemen dan organisasi merupakan aspek yang cukup penting dianalisis untuk kelayakan suatu usaha. Tujuan studi kelayakan aspek manajemen dan organisasi adalah untuk mengetahui apakah dalam pembangunan dan implementasi bisnis dapat direncanakan, dilaksanakan, dan dikendalikan sehingga bisnis rencana bisnis layak atau tidak layak. 
Aspek Ekonomi dan Sosial merupakan aspek studi kelayakan bisnis yang bertujuan untuk mengetahui seberapa jauh lingkungan luar memberikan peluang dan sekaligus ancaman bagi rencana bisnis. Selain itu juga untuk mengetahui apa saja yang dapat disumbangkan oleh proyek bisnis bagi lingkungan luar, jika bisnis sudah direalisasi.

Aspek keuangan merupakan aspek yang digunakan untuk menilai keuangan perusahaan secara menyeluruh dan merupakan salah satu aspek yang sangat penting untuk dinilai kelayakannya. Tujuan penilaian aspek keuangan adalah untuk mengetahui prakiraan pendanaan dan aliran kas proyek bisnis, sehingga dapat diketahui layak atau tidaknya suatu rencana bisnis yang dimaksud. Aspek keuangan menilai sumber dana, biaya investasi, estimasi aliran kas (Cash Flow), biaya modal (Cost of Capital), Kriteria Penilaian Investasi.

Metode Net Present Value (NPV) adalah metode yang menghitung selisih antara nilai sekarang investasi (capital outlays) dengan nilai sekarang penerimaanpenerimaan kas bersih (present value of proceed) baik dari operastional cash flow maupun dari terminal cash flow pada masa yang akan datang (selama umur investasi).

Metode Internal Rate of Return (IRR) adalah tingkat bunga yang menjadikan NPV sama dengan nol, karena present value dari cash flow pada tingkat bunga tersebut sama dengan internal investasinya. Metode Internal Rate of Return (IRR) adalah metode yang menghitung tingkat bunga yang menyamkan nilai sekarang investasi dengan niali sekarang penerimaanpenerimaan kas bersih.

Metode Payback Period (PP) merupakan teknik penilaian terhadap jangka waktu (periode) pengembalian investasi suatu usaha dengan cara mengukur seberapa cepat suatu investasi kembali, dengan demikian metode ini mengukur rapidity kembalinya dana investasi bukan mengukur profitability.

Metode Average Rate of Return (ARR) adalah metode yang mengukur seberapa besar tingkat keuntungan rata-rata yang diperoleh dari suatu investasi dengan cara membandingkan laba setelah pajak (EAT) terhadap rata-rata investasinya. Metode Profitability Index (PI)adalah metode yang menghitung perbandingan antara nilai sekarang penerimaan kas bersih di masa yang akan datang (selama umur investasi) dengan nilai sekarang investasi (initial investment).

\section{METODE PENELITIAN}

Penelitian ini menggunakan jenis penelitian studi kasus yakni jenis penelitian yang relevan dari hasil penelitian pada obyek penelitian yang mencoba mengetahui dan memecahkan permasalahan yang dihadapi perusahaan.Data yang digunakan dalam penelitian ini adalah data primer dan data sekunder. Data primer adalah data yang diperoleh atau dikumpulkan langsung dari sumber asli (tanpa perantara). Dalam hal ini data primer tersebut berupa hasil wawancara yang dilakukan oleh peneliti kepada pemilik usaha Rumah Pemondokan (kost) mahasiswa. 
Data sekunder adalah data yang diperoleh dalam bentuk yang sudah jadi, sudah dikumpulkan dan diolah oleh pihak lain. Data sekunder dalam penelitian ini yaitu data laporan keuangan usaha, sumber modal yang digunakan dan data pendapatan pada rumah pemondokan (kost) mahasiswa.

Dalam mengumpulkan data yang diperlukan untuk penelitian, maka Teknik pengumpulan data yang dilakukan dalam penelitian ini adalah dengan melakukan observasi, wawancara, dan dokumentasi. Observasi yaitu menggunakan pengamatan secara langsung di lapangan. Hal ini dilakukan dalam rangka melakukan pengamatan secara langsung kegiatan usaha rumah pemondokan (kost) mahasiswa.

Wawancara/interview, dalam penelitian ini teknik pengumpulan data di lakukan dengan cara melakukan tanya jawab dengan pemilik rumah pemondokan (kost). Hal ini dilakukan dalam rangka mengambil data mengenai sejarah berdirinya rumah pemondokan (kost), gambaran umum usaha rumah pemondokan (kost) mahasiswa. Dokumentasi dalam penelitian ini proses pengumpulan data dilakukan dengan cara mempelajari dokumen pendukung serta mencatat secara langsung data yang tersedia pada obyek penelitian. Hal ini dilakukan dalam rangka memperoleh data berupa: Laporan keuangan, data jumlah kamar, data tarif rumah pemondokan, data fasilitas rumah pemondokan.

Data yang telah terkumpul dapat dianalisis dengan menggunakan teknik Analisis yaitu pada aspek pasar dan pemasaran adalah aspek pasar memberikan informasi permintaan pasar (Market Demand) atas hasil usaha dalam penelitian ini berupa volume penjualan rumah pemondokan (kost) mahasiswa, tarif yang dikenakan, segmentasi dan target pasar, dan pesaing usaha. sedangkan aspek pemasaran memberikan informasi tentang strategi dan siasat pemasaran atau promosi yang dilakukan oleh pemilik kost.

Analisis aspek teknis dan teknologi memberikan informasi deksripsi produk, fasilitas yang tersedia, biaya operasi, dan tata letak (layout) kost mahasiswa. Aspek organisasi dan manajemen Memberikan informasi perencanan (planning), pengorganisaian (organizing), pelaksanaan (actuating), dan pengawasan (controlling). tugas dan tanggun jawab personil, dan gaji insentif.

Analisis aspek ekonomi dan sosial mengungkap pengaruh dan manfaat yang didapat dari berdirinya usaha rumah pemondokan (kost) mahasiswa terhadap perkembangan daerah dan penduduk usaha rumah pemondokan (kost) yang terkait, dan biaya sosial yang telah dikeluarkan.

Aspek Keuangan Menentukan pembiayaan proyek, berapa besarnya kebutuhan dana dan sumbernya, biaya dana baik untuk keperluan investasi maupun untuk keperluan modal kerja proyeksi arus kas bersih, biaya penyusutan, bunga pinjaman, dan terminal cash flow. Melakukan penilaian investasi dengan kriteria penilaian investasi yang terdiri dari metode Net Present Value (NPV), metode Internal Rate of Raturn (IRR), metode Payback Periode, 
metode Average Rate of Return (ARR), metode Profitability Index (PI).

\section{HASIL PENELITIAN DAN PEMBAHASAN}

Berdasarkan aspek pasar dan pemasaran, rumah pemondokan milik Bapak Rofiq dinyatakan layak karena produk yang ditawarkan telah sesuai dengan harga yang ditawarkan,

fasilitas memadai dengan harga yang terjangkau. Strategi yang dilakukan dalam memasarkan usaha rumah pemondokan seperti promosi penjualan dengan menggunakan brosur, juga menyebar dengan sendirinya dari mulut ke mulut memberi pengaruh terhadap permintaan usaha rumah pemondakan milik Bapak Rofiq selebihnya hanya memasang papan sebagai informasi terima kost.

Sama halnya dengan rumah pemondokan milik Ibu Atnah, dengan memasang harga yang lebih murah namun fasilitas disesuaikan dengan harga, cukup menarik perhatian karena terkesan lebih murah dengan sistem pembayaran bulanan. Promosi penjualan dengan menyebarkan brosur semenarik mungkin memberi pengaruh positif, selebihnya informasi tersebar dari mulut ke mulut dan memasang papan sebagai informasi terima kost, maka dilihat dari aspek pasar dan pemasaran usaha rumah pemondokan milik Ibu Atnah dinyatakan layak.

Rumah pemondokan milik Bapak Sofi disewakan dengan harga yang murah setiap tahunnya fasilitas memadai dan berada di kawasan perumahan yang asri, dengan kondisi bangunan yang baru dan harga yang terjangkau mampu menarik perhatian banyak konsumen. Tidak ada strategi pemasaran secara khusus, hanya memberi informasi dengan memberi banner di rumah tersebut bahwa rumah terebut disewakan. Hal itu cukup berpengaruh, karena banyak konsumen yang menghubungi no telepon yang tertera pada banner, disamping itu pemilik menitipkan pada petugas keamanan agar ikut mempromosikan rumah Bapak Sofi kepada konsumen dan hasilnya rumah tersebut sejak di kontrakan selalu ada konsumen yang berminat.

Berdasarkan Aspek Teknis dan Teknologi, Rumah pemondokan milik Bapak Sofi dinyatakan layak karena rumah pemondokan ini menyediakan fasilitas lengkap meliputi kamar 4mx3m sebanyak 19 kamar, dan 3 kamar lainnya $5 \mathrm{mx} 4 \mathrm{~m}$ setiap kamar terdapat tempat tidur, lemari pakaian, meja, kursi dengan fasilitas pendukung seperti ruang tamu, ruang santai, dapur dan beberapa kamar mandi, dan lahan parkir, lokasi rumah pemondokan sangat strategis dekat dengan jalan raya dan kampus UMM.

Rumah pemondokan milik Ibu Atnah berdasarkan aspek teknologi dinyatakan layak karena menyediakan fasilitas kamar $4 \mathrm{mx} 4 \mathrm{~m}$ sebanyak 15 kamar, setiap kamar mendapat tempat tidur, meja dan lemari dengan harga yang sesuai. Fasilitas pendukung lainnya adalah lahan parkir yang luas, dapur, ruang tamu, ruang santai, dan beberapa kamar mandi. Lokasi rumah pemondokan tidak dekat dengan jalan raya tetapi masih mudah mengaskes apa pun karena banyak penjual makanan, percetakan, sarana ibadah, sarana kesehatan dan lainlain. 
Rumah pemondokan milik Bapak Sofi dari aspek teknis dan teknologi dinyatakan layak karena lokasi rumah yang berada di kawasan perumahan New bukit villa sengkaling memberi kesan asri dan memilik pemandangan yang indah. Bangunan rumah yang nyaman dan baru dengan luas bangunan $54 \mathrm{~m} 2$, luas tanah $136 \mathrm{~m} 2$, jumlah kamar 2, kamar mandi 1 , ruang tamu, dapur, halaman depan dan belakang yang luas dengan fasilitas 2 tempat tidur, meja, dan kursi. Rumah ini dekat dengan pos keamanan sehingga mudah mengawasi keamanan dari rumah ini.

Berdasarkan Aspek manajemen dan organisasi, rumah pemondokan milik Bapak Rofiq dinyatakan layak karena dilihat dari Planning, Organizing, Actuating, dan Controling pemilik menjalankannya dengan tepat, dengan jumlah tenaga kerja 2 orang cukup melancarkan aktivitas usaha rumah pemondokan. Jumlah Karyawan akan ditambah apabila pemilik melakukan ekspansi. Dengan melakukan pengawasan sesering mungkin, respon yang cepat, dan terbuka terhadap kritik dan saran dari konsumen membuat rumah pemondokan ini terus mengalami kemajuan. Pemberian gaji yang disesuaikan dengan jenis pekerjaan beserta tambahan tunjangan hari raya diharapkan dapat memotivasi kerja bagi pekerja.

Rumah pemondokan milik Ibu Atnah dilihat dari aspek manajemen dan organisasi dinyatkan layak, karena pemilik melakukan perencanaan hingga mengambil keputusan berdasarkan pengamatan yang dilakukan sehari-hari, karena tinggal satu atap dengan konsumen, sehingga memudahkan dalam melakukan pengawasan, dan dibantu dengan 1 orang tenaga kerja sebagai pembantu untuk mengawasi dan membersihkan rumah pemondokan. Pemberian gaji yang disesuaikan dengan jenis pekerjaan beserta tambahan tunjangan hari raya dan fasilitas tempat tinggal diharapkan dapat memotivasi kerja bagi pekerja.

Rumah pemondokan milik Bapak Sofi dilihat dari aspek

manajemen dan organisasi layak karena meskipun pemilik tinggal di luar kota hanya bisa memantau pada saat hari libur, dan memantau via telepon atau sms kepada konsumen, usaha ini tetap berjalan. Tidak ada tenaga kerja yang dipercayakan untuk mengawasi rumah milik Bapak Sofi karena memang tidak diperlukan tenaga kerja dalam usaha ini. Selama ini pemilik menggunakan sistem kepercayaan dengan melakukan pendekatan kepada konsumen agar terjalin komunikasi yang baik dan hubungan yang baik.

Berdasarkan Aspek ekonomi dan sosial, rumah pemondokan milik Bapak Rofiq dinyatakan layak, karena banyak dampak positif yang ditimbulkan dari berdirinya rumah pemondokan milik Bapak Rofiq, baik keuntungan bagi pemilik maupun banyak pihak luar baik secara finansial maupun secara fisik. Begitu pula dengan rumah pemondokan milik Ibu Atnah, berdirinya usaha ini memberi dampak positif bagi pemilik maupun pihak-pihak lain.

Rumah pemondokan milik Bapak sofi juga memberi dampak positif terutama bagi pemilik secara finansial dan dengan adanya yang menempati rumah tersebut, akan ada yang memelihara rumah tersebut. 
Pengaruh lainnya adanya perubahan lingkungan dengan bermunculan usaha-usaha sejenis maupun tidak sejenis, dan adanya perubahan lingkungan secara fisik yang lebih baik.

Ketiga rumah pemondokan tersebut memiliki biaya khusus yangdipergunakan untuk biaya sosial sebagai aksi sosial yang dilakukan oleh pemilik usaha.

Tabel 2. Kesimpulan Hasil Kriteria

Kelayakan Rumah Pemondokan Milik Bapak Rofiq

\begin{tabular}{|c|c|c|}
\hline $\begin{array}{l}\text { Kriteria } \\
\text { Investasi }\end{array}$ & Hasil & Keterangan \\
\hline NPV & $226.968 .193,1$ & $\begin{array}{l}\text { Layak karena NPV } \\
\text { bernilai positif } \\
226.968 .193 .1>0\end{array}$ \\
\hline IRR & $17,2063 \%$ & $\begin{array}{l}\text { Layak karena IRR } \\
17,2063 \%>15 \%\end{array}$ \\
\hline PP & 6,104 & $\begin{array}{l}\text { Layak karena PP yaitu } 6 \\
\text { tahun, } 1 \text { bulan, } 7 \text { hari < } \\
\text { umur ekonomis yaitu } 20 \\
\text { tahun }\end{array}$ \\
\hline ARR & $43 \%$ & $\begin{array}{l}\text { Layak karena ARR } 43 \% \\
>r=15 \%\end{array}$ \\
\hline PI & 1,44 & Layak karena PI $1,44 \geq 1$ \\
\hline
\end{tabular}

Berdasarkan Tabel 2 hasil analisis usaha rumah pemondokan milik Bapak Rofiq menunjukan bahwa biaya investasi yang telah dikeluarkan bisa menjadi menguntungkan dari tahun ke tahun. Bila dilihat dari Hasil analisis Net Present Value (NPV) positif atau $>0$ maka dinyatakan layak. Payback Period (PP) diperoleh < umur ekonomis maka dinyatakan layak. Hasil nilai Internal Rate of Return (IRR) lebih besar > COC maka dinyatakan layak, nilai Average Rate of Return (ARR) > tingkat keuntungan yang diharapkan yaitu maka dinyatakan layak. dan nilaiProfitability Index $(\mathrm{PI}) \geq 1$ maka usaha ini dinyakan layak. Hasil analisis menyatakan bahwa usaha rumah pemondokan milik Bapak Rofiq dari aspek keuangan dinyatakan layak.

Tabel 3menunjukkan hasil analisis usaha rumah pemondokan milik Ibu Atnah menunjukan bahwa biaya investasi yang telah dikeluarkan dari modal sendiri dan pinjaman bank, bisa menjadi menguntungkan dari tahun ke tahun. Bila dilihat dari Hasil analisis $\mathrm{Net}$ Present Value (NPV) positif atau $>0$ maka dinyatakan layak. Nilai Payback Period (PP) kurang dari umur ekonomis maka PP dinyatakan layak.

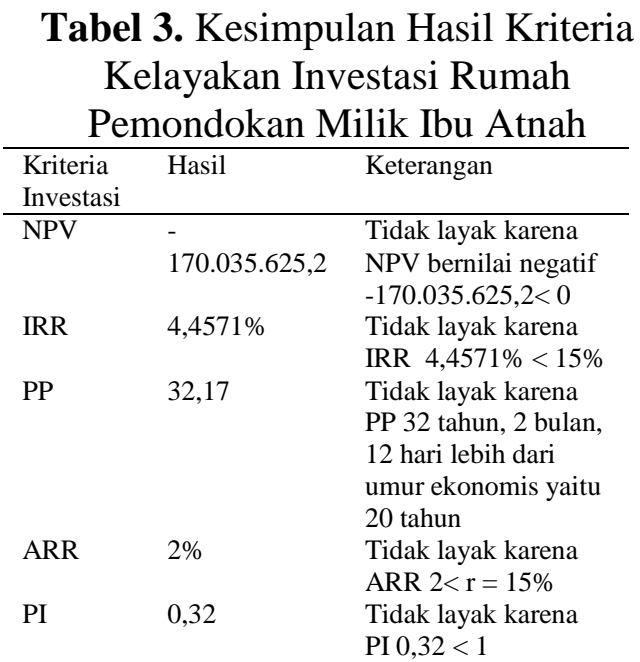

Sumber: Data keuangan rumah pemondokan milik Ibu Atnah

Hasil nilai Internal Rate of Return (IRR) lebih besar > COC maka dinyatakan layak, nilai Average Rate of Return (ARR) lebuh besar dari tingkat keuntungan yang diharapkan maka dinyatakan layak. dan nilaiProfitability Index (PI) $\geq 1$ maka usaha ini dinyakan layak. Berdasarkan hasil analisis menyatakan bahwa usaha rumah pemondokan milik Ibu Atnah dilihat dari aspek keuangan dinyatakan layak. 
Tabel 4menunjukkan hasil analisis usaha rumah pemondokan milik Bapak Sofi menunjukan bahwa modal yang telah dikeluarkan untuk usaha kurang menguntungkan. Dari sisi pertumbuhan selalu meningkat namun penerimaan yang diterima kurang bila dikurangi biaya pengeluaran di awal-awal usaha. Bila dilihat dari Nilai Net Present Value (NPV) Hasil analisis Net Present Value (NPV) negatif atau $<0$ maka dinyatakan tidak layak. Nilai Payback Period (PP) diperoleh lebih dari umur ekonomis maka dinyatakan tidak layak.

Tabel 4. Kesimpulan hasil kriteriakelayakan Investasi RumahPemondokan Milik Bapak Sofi

\begin{tabular}{|c|c|c|}
\hline $\begin{array}{c}\text { Kriteria } \\
\text { Investasi }\end{array}$ & Hasil & Keterangan \\
\hline NPV & $22.370 .869,3$ & $\begin{array}{l}\text { Layak karena NPV } \\
\text { bernilai positif Rp } \\
22.370 .869,3>0\end{array}$ \\
\hline IRR & 18 & $\begin{array}{l}\text { Layak karena IRR } 18 \% \\
>17 \%\end{array}$ \\
\hline PP & 12,23 & $\begin{array}{l}\text { Layak karena PP } 12 \\
\text { tahun, } 2 \text { bulan, } 23 \text { hari } \\
\text { kurang dari umur } \\
\text { ekonomis yaitu } 20 \text { tahun }\end{array}$ \\
\hline ARR & $38 \%$ & $\begin{array}{l}\text { Layak karena ARR } 38 \% \\
>\mathrm{r}=17 \%\end{array}$ \\
\hline PI & 1,058 & $\begin{array}{l}\text { Layak karena PI } 1,058 \geq \\
1\end{array}$ \\
\hline
\end{tabular}

Sumber: Data keuangan rumah pemondokan milik Bapak Sofi.

Hasil nilai Internal Rate of Return (IRR) < COC maka dinyatakan tidak layak, nilai Average Rate of Return (ARR) < tingkat keuntungan yang diharapkan maka dinyatakan tidak layak. dan nilaiProfitability Index (PI) $<1$ maka usaha ini dinyatakan tidak layak. Dari hasil analisis menyatakan bahwa usaha rumah pemondokan milik Bapak Sofi dilihat dari aspek keuangan dinyatakan tidak layak.
Berdasarkan hasil dari aspek keuangan, khusunya untuk rumah pemondokan milik Bapak Sofi, perlu ditindak lanjuti mengapa hasil dari aspek keuangan tidak layak. Hal ini dikarenakan untuk tipe rumah yang dimiliki Bapak Sofi seharusnya memasang tarif lebih tinggi agar mendapat keuntungan di awal pendirian usaha. Dalam menentukan harga perlu dipertimbangkan baikbaik dan disesuiakan dengan spesifikasi rumah milik Bapak Sofi, agar tidak merugi. Karena pendapatan yang diperoleh relative minim, sebaiknya tidak mengeluarkan biaya yang tidak diperlukan terlebih dahulu karena pendapatan lebih kecil dari pengeluaran.

\section{SIMPULAN}

Berdasarkan hasil analisis aspek pasar dan pemasaran, aspek teknis dan teknologis (produksi/operasi) aspek manajemen dan organisasi, aspek ekonomi dan sosial, aspek keuangan menunjukan bahwa usaha rumah pemondokan milik Bapak Rofiq dan milik Ibu Atnah layak untuk dilanjutkan, untuk rumah pemondokan milik Bapak Sofi berdasarkan hasil analisis aspek pasar dan pemasaran, aspek teknis dan teknologis (produksi/operasi), aspek manajemen dan organisasi, aspek ekonomi dan sosial usaha rumah pemondokan milik Bapak Sofi layak untuk dilanjutkan, sedangkan dari aspek keuangan menunjukan bahwa usaha rumah pemondokan milik Bapak Sofi tidak layak untuk dilanjutkan. 
DAFTAR PUSTAKA

Abdul Halim. 2005. Analisis Investasi. Salemba Empat, Jakarta.

Agus Sucipto, M.M, 2010. Studi Kelayakan Bisnis.UIN-Maliki Press, Malang.

Didit Herlianto dan Triani pujiastusi, 2009. Studi Kelayakan Bisnis. Graha Ilmu, Yogyakarta

Gitman, Lawrence J. 2000. Principles of Managerial Finance, edisi 9. Addisom Wesley Publising Co, New York.

H. Indriyo Gitosudarmo, M.Com (Hons) dan Drs.H Basri, M.M. 2002. Manajemen

Keuangan Edisi 4. Penerbit BPFEYOGYAKARTA.

Husein Umar, 2003. Studi Kelayakan dalam Bisnis Jasa. PT Gramedia Pustaka Utama, Jakarta.

Iman Soeharto, 1990. Manajemen Proyek industri (persiapan, pelaksanaan, pengelolaan). Penerbit erlangga, Jakarta.
Kasmir, S.E., MM dan Jakfar, S.E., MM 2003. Studi Kelayakan Bisnis. Prenada Media, Jakarta Timur.

Murdifin Haming, S.E., M.Si dan Salim Basalamah, S.E., M.Si. 2003. Studi Kelayakan Investasi Proyek dan Bisnis. Penerbit PPM, Jakarta.

Santoso, Singgih dan Tjiptono, Fandy, 2001. Riset Pemasaran: Konsep dan Aplikasi dengan SPSS. PT Elex Media Komputindo, Jakarta.

Wiliam, Gordon dan Jeffry, 1995. Investment. Prentice Hall Inc.

Wahyu Sutrisno, 2013.Evaluasi Kelayakan Bisnis pada Usaha Jasa King Laundry.Universitas Muhammadiyah Malang.

UU no. 172002 Tentang Pajak Penghasilan Pasal 11.

http://www.malangkota.go.id/mlg. Perkembangan Pendidikan di kota Malang. Diunduh pada tanggal 18 November 2013.

http://www.PenyusutanAktivaTetapMenur utPajakTerbaruAkuntansiItuMudah .com.Penyusutan aktiva tetap berdasarkan pajak. Diunduh pada tanggal 04 maret 2014. 